\title{
THE POLITICAL ECONOMY OF INCORPORATION: Black Sociologists in Academia
}

\author{
Stephen Kulis
}

This study examines institutional variations in the recruitment of black sociologists in academia and in racial allocations of academic rank. It is designed to identify aspects of the academy that pose barriers to equal participation for black sociologists and to suggest institutional structures and environments that are most likely to equitably incorporate them. Drawing on a 1984 national survey of sociology departments $(\mathrm{N}=230$ ), the study examines both the absolute and proportional representation of black sociologists at the departmental level, as well as issues of tokenism and equality in the assignment of academic rank among racially integrated departmental faculties. Results indicate that the factors that promote better black faculty representation do not always provide African-Americans with other black colleagues, with substantial numerical influence within the department, or with equality in academic rank. Those colleges and universities that are most likely to have black sociologists are large, have sizable black student populations, and are located in metropolitan areas or the South. Racial equality in academic rank is most closely associated with dependence on government revenues.

At. each stage of an academic career, from high school graduation through promotion to the rank of full professor, African-Americans are successively more scarce (National Science Foundation, 1988a). Recent downward trends are especially striking among recipients of advanced degrees: The number of African-Americans earning doctoral degrees declined by 22 percent between 1978 and 1988, and decreased at more than double that rate among black men (American Council on Education, 1989). These decreases far outpaced a general drop in doctoral production. During the period the proportion of all docto-

Stephen Kulis, Department of Sociology, Arizona State University, Tempe, AZ 85287-2101.

*Data for this study were collected with financial support from the American Sociological Association, the Pacific Sociological Association, and the University of Oregon Center for the Study of Women in Society. Support for the analysis came from the National Science Foundation (SES-8922477) and an Arizona State University Faculty Grant-in-Aid. I am grateful to K. Jill Kiecolt, Karen A. Miller and A. Wade Smith for their comments and suggestions. Any errors of commission, omission or interpretation are mine alone. 
rates conferred on African-Americans dropped from 4.1 to 3.5 percent, while that for Hispanics and Asian-Americans grew appreciably. Moreover, black college faculty members dwindled in number and proportion from the late 1970s to the mid-1980s, while the Asian-American and Hispanic professoriate expanded (American Council on Education, 1986).

The severe underrepresentation of African-Americans among doctoral recipients and college faculty, now regularly documented, can be attributed readily to short supplies of black students at earlier junctures in the education pipeline.' While miniscule numbers of new doctoral recipients certainly limit black representation on college faculties, there may be an important "demand" side to the problem as well. Various critics have suggested that organizational barriers, located within the structure and environment of the academy, deflect AfricanAmericans from full and equitable incorporation into postsecondary faculties (Epps, 1989; Menges and Exum, 1983; Moore, 1988; Wood, 1988). Little is known with certainty about the institutional contexts within academia that are most successful in recruiting, retaining, and equitably rewarding black faculty. Large-scale comparative studies have yet to establish whether distinctive economic and/or political factors are at work within those institutions of higher education that have made greater strides toward full participation for black faculty.

This paper elaborates a political-economy model to assess the impact of organizational and institutional factors on the participation of black sociologists as faculty members in four-year colleges and universities in the United States during the early 1980s. The principal objective is to relate differences in the employment outcomes of black and nonblack sociology faculty to variations in the structure and environment of academic organizations and departments. The paper attempts to clarify the institutional locations of black sociologists in academia, and to identify the types of institutions where they are most likely to find multiple black colleagues and racially equitable allocations of academic rank.

\section{BLACK SCHOLARS IN THE ACADEMY}

Prior investigations into the declining presence of minority doctoral students and college faculty suggest three types of explanations, each reflecting certain methodological limitations: (1) studies of the academic labor market "niches" occupied by black faculty; (2) explorations into the social psychology of intergroup relations in settings where black workers are small minorities; and (3) studies that analyze trends in the supply of black students and scholars to suggest the causes and consequences of their underrepresentation in higher education. 


\section{The Black Academic's Labor Market}

The concentration of black faculty in historically black colleges, and in a few disciplines-education, social sciences, psychology, life sciences, and social work (National Science Foundation, 1988b)_-suggests that the academic labor market may operate differently for black than for white scholars. Historically black colleges are especially important because of their leading role in the production of black professors (Pearson, 1985; Conyers and Epps, 1974). Studies of the attractions and limitations of these institutions for their black faculty provide suggestive leads to the obstacles that black academics may encounter in predominantly white institutions. For example, black faculty in historically black colleges and universities report that they are attracted to better working conditions (e.g., longer probationary periods, more certain prospects of tenure, better salary), the special mission of the college, a shared desire to contribute to black people, and the sincerity of recruiters (Harvey and Williams, 1989). This suggests that academic employers are able to govern entry into, and movement within, the higher education labor market in ways that may aid or impede the incorporation of black scholars.

Given longstanding concern over the level of black participation in higher education, surprisingly little research has examined the working conditions and careers of black faculty in predominantly white institutions. Comparative studies indicate that the level of formal education and the prestige of the graduate program that granted the faculty member's degree are higher among black faculty at predominantly white than at historically black colleges (Blackburn and Young, 1985). The latter are more likely to stress a teaching orientation, where involvement in publication (Newby, 1982) and time for research (Williams, 1985) are limited. We also know that black faculty in predominantly white institutions are disproportionately concentrated in lower academic ranks, in untenured positions (Linthicum, 1989; Stepina and Campbell, 1987), and in small institutions with high teaching loads (Conyers and Epps, 1974). AfricanAmericans also earn less than whites in every natural and social science or engineering discipline (National Science Foundation, 1988a), although these comparisons do not control for differences in work experience or productivity.

Some maintain that there is a legacy of discrimination in administrative and collegial practices in predominantly white institutions (Moore, 1988): white control over faculty search processes, criteria, and interviewing; white-dominated nomination and insider information networks; and heightened scrutiny of minority candidates under the guise of maintaining standards and resisting special-interest politics. This view is backed by the large majorities of black faculty in predominantly white colleges and universities who report that they have encountered discriminatory practices (Moore and Wagstaff, 1985; Harvey, 1987). Indeed, Sudarkasa (1987) contends that most black faculty members 
obtain their positions without preferential treatment through affirmative action programs, and despite discrimination.

The Social Psychology of Tokenism

Even after obtaining an appointment, black faculty may face serious obstacles in securing the normal rewards of academic life within majority white departments. Simply because of their relative scarcity, they may move uneasily within a "fishbowl" where their performance is subjected to unusually close and unrelenting scrutiny. Many are cast in solo roles (Kanter, 1977) amid an otherwise all-white department. Moreover, in many organizational settings solo blacks are assumed to be tokens (Fernandez, 1982) whose appointments result from affirmative action programs. When these affirmative action programs are highly visible, as in academia, even nonsolos who join the company of other black colleagues may be perceived as tokens. Experimental and field studies indicate that token status has negative consequences for underrepresented individuals because they are presumed to be incompetent (Kanter, 1977; Northcraft and Martin, 1982). Tokens are expected to perform at exaggerated (usually lower) levels, which may become self-fulfilling, and are then subjected to extreme evaluations as well (see Pettigrew and Martin, 1987, for a review of studies). Solo roles may be structurally disadvantaged (Kanter, 1977) in that their heightened visibility prompts more intense scrutiny by the majority, imposing uncomfortable dilemmas of self estrangement in the assimilation process. Kanter argues that as the proportional representation of -a minority increases, the majority exercises less certain control, minorities are more likely to be treated as individuals rather than as symbols or representatives of entire groups, and possibilities for integrated alliances open up. A minority's share of faculty positions is a possible gauge, then, of its political efficacy within the institution.

The Uncertain Causes and Consequences of Undersupply

Perhaps the most prominent studies of black scholars-those using aggregate data from the National Research Council's Survey of Earned Doctorates and Survey of Doctoral Recipients-focus on the labor economics of "supply." They have documented the shrinking cohorts of minority doctoral recipients, resulting decreases in applicant pools, and increased interest in nonacademic careers among minority doctoral recipients (Brown, 1988; National Science Foundation, 1988b). Based on strong methodologies and large data bases, these studies monitor trends in the level of underrepresentation of minorities at suc- 
cessive junctures in the education system. More speculative studies have sought to uncover the cause of these downward trends by linking them to the escalating cost of higher education, the withdrawal of adequate sources of financial aid, and expanding opportunities in more lucrative fields outside academia (Brazziel, 1988).

The constricted supply of black doctorates has been amply documented (American Council on Education, 1986, 1989), but its consequences are more dimly understood. There is a growing perception, supported anecdotally, that the limited number of black doctoral recipients is heightening the competition to attract them to college faculties (Chandler, 1988). Aggressive recruitment efforts directed at minority scholars are viewed as creating a form of "musical chairs," as institutions attempt to hire black faculty away from each other (Mooney, 1989). This is seen as enhancing black scholars' prospects for upward mobility to successively more prestigious institutions, and perhaps to more desirable work and salary conditions. There is little doubt that increased demand, coupled with a small pool of candidates, makes minority recruitment difficult (New Jersey State Department of Higher Education, 1986). But it is unclear whether colleges and universities actively vie to attract black scholars generally or focus on luring away a small number of highly visible black scholars, just as white faculty "stars" are aggressively courted (Magner, 1990).

Several important statistics suggest that the "musical chairs" phenomenonif it takes place at all-has not enhanced the career prospects of all black scholars uniformly. Unemployment and underemployment rates among black scientists are double those of their white counterparts, and black scientists are also more likely to be employed outside their fields of training (National Science Foundation, 1988a). Moreover, the proportional representation of black faculty nationwide declined steadily after 1976, despite growth in the number of black Ph.D.s during the late 1970s. This suggests that supply factors alone cannot account for the underrepresentation and employment conditions of black academics.

This study brings together aspects of the three distinct approaches taken by prior studies. First, we advance a conceptual framework that identifies a set of institutional factors that arguably represent barriers to equal participation for black scholars in academia. Rather than relying on black faculty respondents to identify these barriers, they are measured as features of the organizational structure and environment of a large sample of colleges and universities. We also document the extent to which black faculty are placed in "token" or "solo" positions at the departmental level, and identify the institutional settings where these conditions are most likely to occur. Finally, we consider important aspects of the supply issue by examining regional and geographic variations in the representation of black faculty. 


\section{A POLITICAL-ECONOMY MODEL OF RACIAL EQUITY IN ACADEMIA}

Rather than emphasizing racial differences in socialization, education, work experience, and achievement, this study links the level of participation of black faculty to the structure of academic labor markets and academic organizations. It attempts to examine both demand- and supply-side factors in the academic labor market and investigates their facilitating or inhibiting influence on the participation of black faculty. We follow a course chosen increasingly by studies of the segregation of minorities and women within the less desirable corners of the occupational sphere (Breneman and Youn, 1988; Pettigrew and Martin, 1987), which demonstrate how institutional structures shape individual careers, sometimes with different implications for some groups than for others. We distinguish internal labor markets, which refer to specific organizational settings, administrative procedures, and divisions of labor, from the external labor markets that create variations in the supply and competition for labor, and that direct the flow of labor into various occupations, jobs, and organizations (Kalleberg and Sorensen, 1979). For some time now, studies of internal labor markets in academia have highlighted the impact on minorities and women of the institution's size, prestige, and research emphasis (Bernard, 1964; Blau, 1973). More recent studies of external labor market factors have targeted the level of competition for faculty among colleges and universities (Szafran, 1984); the "density" of opportunities for faculty appointments in the area (Marwell, Rosenfeld, and Spileman, 1979); and the institution's proximity to graduate schools that produce most of the new scholars (McGinnis and Long, 1988).

Each academic institution, and perhaps each of its departments, can be seen as an internal labor market with specific formal and informal rules governing entry, promotion, and access to rewards, thereby constraining opportunities differently for black academics than for their white counterparts. The process of gaining entry, earning promotions, and maximizing one's salary depends not only on one's credentials and experience, but also on attributes of a particular academic institution. Each institution is also situated in a position of relative advantage or disadvantage to the operations of external labor markets that supply academic labor, and within a larger political context. To explain institutional variations in the treatment of groups traditionally underrepresented in higher education, Szafran (1984) distinguished economic and political factors at work within academia's internal and external labor markets. The present study expands on his list of factors to predict which institutions will be most likely to recruit, retain, promote, and equitably reward black academics (Figure 1).

The internal economy of the academy implements organizational goals within a system for producing teaching and research. This encompasses the internal division of labor, the distribution of resources and rewards, and the modes of operation. Each of these shapes personnel decisions, including efforts 
INTERNAL ECONOMY

"Slack" in Financial Resources

Demand for Labor

College/University Prestige

Research Orientation

Organizational Size

Labor Market Segmentation

-Instructor/Lecturer Positions

-Black Studies Program

EXTERNAL ECONOMY

Population in Local Area

Regional Location

RECRUITMENT OF

BLACK FACULTY

Absolute

Representation

Proportional

Representation

RACIAL DISPARITY IN:

Academic Rank

INTERNAL POLITY ->

Minority/Female Administrators

Student Body Racial Composition

EXTERNAL POLITY --->

Institutional Auspices

Dependence on Governmental Funding

FIG. 1. A political economy model of racial equity in academia

to recruit and reward black faculty. These constraints may appear in the degree to which recruitment and promotion procedures are formalized, in the level of demand for labor, and in the type of credentials sought.

The external economy encompasses the classic concerns of economists regarding factors outside the organization that affect its supply of labor and resources, and the demand for its products or services. Those most clearly affecting the racial composition of an organization include the relative scarcity of the local or regional labor supply of potential black and white employees, and the ability of the labor force to seek optimal rewards among a host of competitors. These too place limits on the options considered by personnel decision makers within the organization.

These constraints do not strip decision makers of all discretion, however. There remains considerable uncertainty about how to identify goals and select options that meet them. This is the realm of the internal polity, which encompasses the formal structure for decision making and more informal influence networks that set and interpret these organizational goals and policies. The values and preferences of those in positions of influence, both individuals and groups within the organization, also can affect equity patterns. Within the internal polity, the degree of centralized authority and the race of those in executive positions can influence personnel processes and outcomes. Decision makers may seek to anticipate the concerns of sizable internal constituencies of black 
employees or "customers" who might exert influence directly through their positions within the organization. And they may be particularly sensitive to the preferences of powerful actors outside the organization-the external polityespecially those like governmental entities that are capable of imposing sanctions or withholding resources (Pfeffer and Salancik, 1978).

The political economy framework outlines the types of organizational factors that may be influential in explaining differences in racial equity across organizational settings, but does not specify a discreet set to be considered. Drawing on the prior discussions and research on racial segregation in academia, and on occupational segregation in general, a more detailed model will now be presented (Figure 1), generating the hypotheses to be tested. The direction of some of these hypotheses is contingent on whether administrative goals have evolved to elevate black faculty recruitment over other institutional priorities. To the extent that this has occurred, the direction of some of our predictions would be reversed.

\section{Factors in the Internal Economy}

"Slack" Finances

Organizations that secure surplus financial resources beyond those minimally necessary for operation provide top administrators with organizational "slack" (Cyert and March, 1963) to act on personal preferences even at the expense of administrative inefficiency (Child, 1972). Financial resources have been cited as important factors in the treatment of underrepresented groups within universities (DiNitto et al., (1982). Slack resources permit institutions to compete aggressively for attractive candidates, but this advantage can be used to promote affirmative action goals or to exercise biases in favor of majority candidates. Thus, the impact of slack financial resources on black faculty recruitment and promotion may be conditioned by political factors that determine policy goals. Slack resources may be enabling conditions that permit change either in the direction of greater or lesser black participation and equity. This leads to our first hypothesis:

H1. "Slack" in financial resources will increase black faculty recruitment and lower racial disparities in academic rank when internal political forces favor racial equity.

\section{Demand for Labor}

An increased demand for labor, as indicated by growth in the number of faculty within an institution, and/or turnover in a constant number of faculty 
positions, also may facilitate change in the faculty's racial composition, if an adequate supply of black labor exists. As with slack resources, demand for labor does not guarantee better opportunities for black scholars but may simply create more jobs for white candidates. Moreover, faculty expansion and turnover may increase black faculty's share of entry-level appointments without redressing disadvantages in proportional representation and in obtaining tenure, promotion, and equitable salaries. In one respect, growing faculties may pose riper conditions for the recruitment of black faculty than faculties with high turnover rates. Without faculty expansion, black faculty can be incorporated only by altering the racial composition of the department. Growth of the faculty may minimize political resistance to black faculty recruitment because the absolute and/or proportional representation of white majorities can be maintained.

H2. When political forces favor racial equity, colleges and universities with expanding faculties and, to a lesser degree, those with high turnover will recruit larger numbers of black faculty.

H3. Faculty expansion will be unrelated to the proportional representation of black faculty and to racial disparities in academic rank.

\section{Prestige}

Institutional prestige is another important factor in the internal economy of higher education. Prestige is a potent resource that can be used to attract recognized scholars and successful researchers (Blau, 1973). Historically excluded from informal prestige networks (Caplow and McGee, 1958), black scholars may have been viewed as less attractive candidates in part because they were presumed to be less effective in recruiting others or in augmenting institutional prestige. In any case, black faculty have clearly been less well represented in top-ranked institutions (National Research Council, 1979), and this legacy may persist. Although small changes began to appear in the 1970s (Hill, 1983; Smelser and Content, 1980) as more prestigious universities began to vie for top black scholars, it appears that the barriers to entry can be more formidable in prestigious schools. At the same time, because prestigious schools may be able to attract the very best scholars, African-Americans who do gain admittance may be more successful in promotion and tenure decisions than their black counterparts in less prestigious schools.

H4. Highly prestigious colleges and universities will be less likely to recruit black faculty, but will have smaller racial disparities in academic rank. 


\section{Research Orientation}

The relative emphasis on research and undergraduate teaching has a direct bearing on personnel decisions in the academy. Historically black colleges, the leading source of black professors before 1960, have traditionally emphasized teaching. This factor, along with isolation from the network of federal funding for research (Bacon, 1974; Leashore, 1985), hampered black contenders for positions at heavily research-oriented institutions. Institutions with strong research orientations may continue to be less hospitable and/or attractive to black candidates, because prospects for promotion remain problematic.

H5. Controlling for prestige, colleges and universities that emphasize research productivity will recruit and reward black faculty less equitably.

\section{Organizational Size}

As in most other organizational settings, institutional size has far-reaching effects on administrative structures and processes within the academy (Blau, 1973). These effects are difficult to isolate because size is closely related to other organizational characteristics. Large size is associated with more formalized recruitment and promotion procedures (Child, 1973; Pfeffer, 1977), which might promote racial equity. But large academic organizations tend to be research-oriented, which may discourage the participation of African-Americans. And size may indicate discretionary or "slack" resources as well (Kimberly, 1976), which might be used either to reduce or to intensify racial inequities. Moreover, large institutions will have more faculty positions to fill, magnifying opportunities to recruit black candidates. If, however, "slack" financial resources, prestige, and faculty growth are held constant, size may be seen to operate as a proxy for formalization. If so, larger colleges and universities should exhibit greater equity both in recruiting and promoting black faculty.

H6. Controlling for research orientation, faculty growth, and slack financial resources, large colleges and universities will exhibit better representation of black faculty and more equitable distributions of academic rank.

\section{Labor Market Segmentation}

A final aspect of the internal economy that may affect African-American representation is the degree of segmentation in the internal labor market (Averitt, 1968; Doeringer and Piore, 1971). Within higher education, labor market segmentation can occur through the creation of special programs or degrees, such as those in Black Studies, or through the assignment of a large proportion of the faculty to instructor or lecturer appointments. A highly seg- 
mented internal market-one that creates secondary sector jobs-may generate employment opportunities for African-Americans that are more likely to be nontenure-track, low in academic rank, low-paid, and/or devoid of opportunities for advancement (Szafran, 1982). In these situations, African-Americans' level of representation may improve absolutely and proportionally, while their rank, tenure, and salary do not.

H7. Institutions with Black Studies programs and those with a large proportion of the faculty in nontenure-track instructor or lecturer, positions will be more likely to recruit black faculty, but less likely to equitably reward them with academic rank.

\section{The External Economy}

A different set of forces originates outside the organization within its external economy. This arena encompasses the factors that affect the academy's supply of labor and resources, and the demand for its educational and research products or services. Those that may affect the racial composition are the relative scarcity of the labor supply of black doctoral recipients, and the level of competition among colleges and universities for their services. Geography plays a crucial role here because of the concentration of the black populace and historically black colleges in certain regions of the country. The academic labor market is marked by regional variations that have important consequences for minority groups. The decision to apply for a faculty position, or to accept it, can be influenced by a desire to remain close (or return) to one's community of origin, and by lifestyle considerations that may require the presence of a sizable black community in the vicinity of the institution. These are more likely to be found if the institution is located in the South, or in a very large metropolis.

H8. Institutions in locales with sizable black populations will be more likely to recruit black faculty, but may not have less racial disparity in academic rank.

\section{The Internal Polity}

\section{Minority/Female Administrators}

Academic administrators influence personnel decisions directly (Caplow and McGee, 1958; Kenen and Kenen, 1978) by establishing criteria for recruitment and promotion, and monitoring their implementation at lower levels. Minority administrators may be more sensitive to discriminatory criteria than white male administrators, and more vigilant in ensuring that these are not employed in recruitment, hiring, or promotion. A sizable contingent of administrators from 
groups traditionally underrepresented in academia-African-Americans, other minorities, and women-can transform organizational culture such that racial and gender bias is minimized among all decision makers. The influence of administrators may be critical to black presence because African-Americans are somewhat better represented among administrators than among faculty (Hankin, 1985), although not necessarily at the highest levels.

H9. Departments chaired by ethnic/racial minorities or women will have more black faculty representation and more equitable allocations of academic rank.

\section{Black "Clients"}

Although they need not take a direct role, black undergraduate constituencies on campus can influence personnel procedures and goals indirectly. Whitemajority colleges and universities with relatively high proportions of black undergraduates may more vigorously recruit and equitably reward black faculty. Where black students comprise a substantial minority, administrators may seek to anticipate their concerns, and may perceive needs to provide black role models of academic success, creating an institutional climate that is more sensitive to black students.

H10. Colleges and universities with relatively high proportions of black undergraduates will more vigorously promote racial equity in recruitment and in the allocation of academic rank.

\section{The External Polity}

Last, we consider two features of the external polity of the institution, both political factors in the organizational environment. Institutional leaders may be particularly sensitive to the preferences of powerful actors outside the organization, especially governmental bodies that can impose sanctions or withhold needed resources. Access to information and accountability presumably are greater in public institutions where personnel policies are highly standardized and the distribution of employee rewards is a matter of public record. Affiliation with government bodies that enforce anti-discrimination statutes may heighten the institution's sensitivity to these issues. Clearly the effect of public accountability on racial equity would depend on how aggressively affirmative action is enforced (Perrucci, 1986), a point of some uncertainty in the 1980s (Jaschik, 1990). In addition, institutions that depend heavily on federal funds may be vigilant to avoid charges of discrimination by developing personnel procedures to prevent its occurrence (Pfeffer and Salancik, 1978; Salancik, 1979). 
H11. Public colleges and universities, and those that are highly dependent on governmental sources of revenue, will recruit and reward black faculty more equitably than those under independent or religious auspices.

\section{METHODOLOGY}

This study examines a single profession, academic sociology, where black scholars are not quite as scarce as in many other disciplines. After substantial increases in the 1970s, the number of new black doctoral recipients in sociology leveled off but did not decline precipitously as in other fields. In the midst of a general decline in doctoral production in all the social sciences, this meant that blacks earned an increasing proportion of new doctoral degrees in the discipline in the early 1980s. 3 When compared to their presence in the population, blacks remain underrepresented in sociology, but not as severely as in most other disciplines, and not in minuscule numbers. In the mid-1980s, blacks comprised about 6 percent of sociology faculty members in four-year institutions, and about 7 percent of sociology graduate students (Kulis et al., $1986 b, 1987)$. The relatively greater success of sociology in attracting black scholars may reflect, in part, the legitimacy this discipline accords issues of racial inequity by recognizing them as proper subjects for scholarly inquiry. By providing more institutional variations in the racial distribution of faculty positions and rewards, the somewhat larger presence of black scholars in sociology makes it feasible to conduct a comparative study of institutional barriers to racial equity. In other fields where black faculty are rare and the annual supply of new black doctoral recipients can be counted on two hands, these questions may be moot, or unanswerable statistically, due to the constraints of extremely small numbers. By exploring organizational contexts where the modest influx of black sociologists has been most-and least-pronounced, our restrictive focus on one discipline holds some promise of identifying salient institutional forces in the incorporation of black faculty generally.

\section{Data}

Data for this study come from a 1984 survey of sociology departments across the United States. The population encompassed all sociology or "social science" departments that offered sociology courses in four-year colleges or universities, as listed in the American Sociological Association Directory of Sociology Departments. The sampling design was hybrid. One part was a complete census of all departments in 13 western states,' designed as a longitudinal follow-up to an identical 1979 survey (Kulis et al., 1986a). A second part was developed to examine the sociology faculty nationwide through a random sample of departments in all the remaining United States, stratified by the size of 
the college or university student population and whether or not the department offered graduate sociology degrees. The two parts combined create an unusual situation with respect to conventional statistical inference, because estimates for departments in the western states have virtually no sampling error. Nevertheless, we report statistical significance information as if all the departments were part of a typical random sample, but note results that meet both standard ( $p$ < $.05)$ and somewhat relaxed $(p<.10)$ thresholds of statistical significance.

Through mailed questionnaires, chairs of eligible departments were asked to enumerate all sociologists in their departments, including adjunct and part-time faculty, and to report their sex, race or ethnicity, rank, tenure status, and committee assignments. They also recorded the sex, race, and ethnicity of faculty who had begun or ended appointments in the department within the previous five years. Extensive efforts at several levels were organized to obtain a high response rate, including the endorsements of the presidents of national and regional sociological associations. Ninety-one percent of eligible departments completed questionnaires, making the weighted sample highly representative of the nation's sociology departments in four-year institutions in 1984. Still it is important to bear in mind the sociologists we have systematically excluded with these procedures: those employed in two-year colleges and those now working in academic disciplines outside sociology. Although the sample comprised 230 departments, some of the analysis utilizes data on 1,634 sociology faculty members in these departments. For most of the analysis, including all tests of the political-economy model (and unless otherwise noted), the department is the unit of analysis.

\section{Operationalization of the Model}

The key dependent variables in the study are aggregate measures of black faculty's status in each department in 1984: (1) a dichotomy indicating the presence or absence of black faculty in the department, (2) the percentage of faculty positions held by African-Americans, and (3) disparities in the distribution of black and nonblack faculty across four academic ranks-full professor, associate professor, assistant professor, and instructor/lecturer. ${ }^{5}$ The index of segregation $H$ developed by Theil and Finizza (1971) was modified to gauge these disparities.' This index differs from most other measures of segregation, such as the index of dissimilarity (Duncan and Duncan, 1955), in that it treats racially skewed distributions at a given academic rank as a more serious indicator of segregation if the racial mix in the department overall is relatively balanced rather than highly skewed as well. This measure varies between 0 and 1 , expressing racial segregation in academic rank relative to the degree of integration that is theoretically possible given the faculty racial composition overall. $H$ records racially unbalanced allocations of academic rank as more seriously 
skewed if black faculty have attained a relatively larger share of departmental positions overall.'

Fourteen independent variables appear in tests of the political-economy model. Each represents an element of the internal or external labor market of the sociology department (or of its academic institution). Slack financial resources are measured by the log of annual institutional expenditures per student. Two measures of the internal economy gauge the size of new opportunities for faculty appointments, the department's "demand for labor." Faculty expansion or contraction is measured as the rate of growth in the number of sociologists in the institution from 1975 to 1984 , specifically the change in faculty size as a percentage of initial size. Faculty turnover is the percentage of initial faculty positions that were vacated and refilled between 1979 and 1984, independent of growth or contraction in the faculty. Another two measures map the degree of segmentation of the institution's internal labor market: the percentage of $\mathbf{1 9 8 4}$ faculty positions in sociology at the instructor or lecturer level, and a dummy variable indicating the existence of a Black Studies program.

Measures of institutional size, prestige, and research orientation are based on confirmatory factor analysis. A factor score for organizational size serves as a proxy for formalization of recruitment and promotion procedures. This multiple indicator measure loads on variables measuring student enrollment and faculty size, both within the department and institutionwide. The same factor analysis produced a second, orthogonal factor relating to the quality and selectivity of the institution's undergraduate degree program, which serves as a measure of institutional prestige. This factor loads heavily on the ratio of undegraduate admissions to applications, the percentage of all faculty who hold doctoral degrees, and average SAT or ACT math and verbal scores for admitted freshmen students. ${ }^{8}$ The prestige of the sociology department was not directly assessed because ratings of sociology programs are limited to departments with graduate programs (Jansen and Webster, 1981), and are strongly related to research orientation (Jones, Lindzey, and Coggeshall, 1982), which the analysis treated separately. This third factor for research orientation taps the following components: extramural research funds as a percentage of the institution's expenditures, the institution's Carnegie Foundation (1987) research classification, total institutional expenditures for research equipment, the number of library volumes in the institution as well as total library expenditures, number of postdoctoral appointments in science and engineering, graduate-degree offerings in sociology, and the number of sociology graduate students. These variables serve as indirect measures of the commitment and availability of resources for research at the departmental and institutional level.

Two measures capture features of the external economy of the department: the size of the city or town and the region in which the institution is located. Size of locale is measured with dummy variables distinguishing large metro- 
politan areas (over 500,000 population) and smaller cities $(50,000-500,000)$ from the towns and rural areas in the reference category. Region is treated similarly, with dummy variables contrasting the Midwest, South, and West against the Northeast as referent.

The internal polity of the department and institution is explored in two ways. A dichotomous variable indicates the presence or absence of a minority or female sociology department chair. Unfortunately, there are too few black or minority department chairs to examine their influence separately. For ease of presentation and discussion, this variable contrasts non-Hispanic white male department chairs with all others. The racial composition of the student body is measured as the percentage of undergraduate students who are African-Americans. In analyses of the entire sample of departments, this measure is logarithmically transformed to obtain a better fit to the data.

Last, there are two measures from the external polity. Institutional dependence on governmental revenues is measured as total funding from state and federal sources as a percentage of total expenditures in 1984. In some analyses, a closely related measure-institutional auspices (public/independent/religious)-appears as well. Descriptive statistics for variables in the model are presented in the Appendix.

The key results of this study are tests of the political-economy model, presented through multivariate logistic and ordinary least squares regression analyses. Because the organizational variables in the model are not expected to influence every facet of racial integration in the same way, we examine their impact on several measures of black faculty participation in turn before summarizing the political-economy effects across dependent variables. In analyses of the absolute and proportional representation of black sociologists two equations are presented, one with and one without the undergraduate racial composition as a predictor. There are two reasons for this. One is that the undergraduate percent black is an overwhelmingly powerful predictor of black faculty representation, and may mediate the effects of other independent variables. Second, because the same institutional factors may increase/hamper the representation of black students and faculty, the inclusion of the former as a predictor of the latter may obscure important correlates of black faculty representation.

\section{RESULTS}

\section{Absolute and Proportional Representation of Black Sociologists}

To begin tracing the institutional locations of black sociologists, we first examine their geographical distribution. Table 1 divides faculty (not departments) into three groups: African-Americans, non-Hispanic whites and nonblack minorities (largely Asian-Americans and a small number of Hispanics).' 
TABLE 1. Regional Distribution of Sociology Faculty in 1984 by Race or Ethnicity

\begin{tabular}{lrrrr} 
& \multicolumn{1}{c}{$\begin{array}{c}\text { Non-Hispanic } \\
\text { Faculty }\end{array}$} & $\begin{array}{c}\text { White } \\
\text { Faculty }\end{array}$ & $\begin{array}{c}\text { Other } \\
\text { Faculty }\end{array}$ & $\begin{array}{c}\text { Faculty } \\
\text { Total }\end{array}$ \\
\hline USA Region: & & & & \\
Northeast & $18(19 \%)$ & $356(25 \%)$ & $29(30 \%)$ & $403(25 \%)$ \\
Midwest & $25(27 \%)$ & $410(29 \%)$ & $21(21 \%)$ & $457(28 \%)$ \\
South & $42(46 \%)$ & $432(30 \%)$ & $26(26 \%)$ & $500(31 \%)$ \\
West & $7(8 \%)$ & $237(16 \%)$ & $23(23 \%)$ & $267(16 \%)$ \\
Total & $92(100 \%)$ & $1435(100 \%)$ & $99(100 \%)$ & $1627(100 \%)$
\end{tabular}

Chi-Square (Region by Race/Ethnicity) $=18.2, \mathrm{p}<.01$

Northeast $=\mathrm{CT}, \mathrm{MA}, \mathrm{ME}, \mathrm{NH}, \mathrm{NJ}, \mathrm{NY}, \mathrm{PA}, \mathrm{RI}, \mathrm{VT}$.

Midwest = IA, IL, IN, KS, MI, MN, NB, ND, OH, SD, WI.

South = AL, AR, DC, DE, FL, GA, KY, LA, MD, MO, MS, NC, OK, SC, TN, TX, VA, WV. West = AK, AZ, CA, CO, HI, ID, MT, NM, NV, OR, UT, WA, WY.

With close to half of their number located in the South, black faculty are more regionally concentrated than others. Though relatively numerous in the South, black faculty are not equally distributed among the departments of that region.

Table 2 switches from faculty to departments as the unit of analysis, and shows that departments in the South are somewhat less likely than those in other regions to have any black faculty members at all. At the same time, southern departments are more likely than those in the West and Northeast to have multiple black faculty. The two tables point to a pattern of regional concentration of

TABLE 2. Number of Black Faculty in Sociology Departments by Region

\begin{tabular}{|c|c|c|c|c|c|}
\hline & Northeast & Midwest & South & West & Total \\
\hline $\begin{array}{l}\text { Number of } \\
\text { Black Faculty } \\
\text { in Departmen }\end{array}$ & & & & & \\
\hline None & $46(79 \%)$ & $45(79 \%)$ & $70(82 \%)$ & $22(80 \%)$ & $182 b(80 \%)$ \\
\hline One & $10(17 \%)$ & $1 \quad(1 \%)$ & $6(7 \%)$ & $4(16 \%)$ & $21 \mathrm{~b} \quad(9 \%)$ \\
\hline Two or more & $3 \quad(4 \%)$ & $11(19 \%)$ & $9(10 \%)$ & $1 \quad(4 \%)$ & $24 \mathrm{~b}(10 \%)$ \\
\hline Totala & $58(100 \%)$ & $57(99 \%)$ & $85(99 \%)$ & $28(100 \%)$ & $227(99 \%)$ \\
\hline
\end{tabular}

Chi-Square (Number of Black Faculty by Region) $=16.6, \mathrm{p}<.05$

aPercentages may not add to 100 due to rounding.

bAll figures in the table are calculated after the application of weights to produce estimates for the nation. Unweighted, there are 174 departments with no black sociologists, 32 with one, and 24 with more than one black sociologist. 
black faculty in a small number of southern departments. The role of historically black colleges and universities is pronounced: Of the 15 southern departments with at least one black faculty member, only two were historically black institutions, but these two contained 40 percent of the South's black sociologists (data not presented in tables). Across the country, regardless of region, only about one of every five departments has any black faculty members at all, a figure that policymakers may see as distressingly low."

The concentration of black faculty also varies by the size of the department and metropolitan area, and by the auspices of the institution. Table 3 returns to the individual level of analysis, showing that black faculty members are much less likely than other faculty to work in small departments, smaller towns, rural areas, and nonpublic institutions. Nearly half of black sociologists reside in large cities, more than double the proportions for white and other minority faculty. African-Americans are also somewhat more likely than non-Hispanic white faculty to secure positions in public institutions, but less likely than all

TABLE 3. Departmental and Metropolitan Size, and Institutional Auspices, by Race or Ethnicity of Sociology Faculty in 1984

\begin{tabular}{|c|c|c|c|c|c|}
\hline & $\begin{array}{c}\text { Black } \\
\text { Faculty }\end{array}$ & $\begin{array}{c}\text { Non-Hispanic } \\
\text { White } \\
\text { Faculty }\end{array}$ & $\begin{array}{c}\text { Other } \\
\text { Faculty }\end{array}$ & & $\begin{array}{l}\text { culty } \\
\text { otal }\end{array}$ \\
\hline \multicolumn{6}{|l|}{ Sociology Department } \\
\hline \multicolumn{6}{|l|}{ Faculty Size: } \\
\hline $1-10$ & $29(31 \%)$ & $701(49 \%)$ & $55(55 \%)$ & 785 & $(48 \%)$ \\
\hline $11-20$ & $40(44 \%)$ & $343(24 \%)$ & $25(25 \%)$ & 408 & $(25 \%)$ \\
\hline $21-50$ & $23(25 \%)$ & $392(27 \%)$ & $20(20 \%)$ & 434 & $(27 \%)$ \\
\hline Total & $92(100 \%)$ & $1436(100 \%)$ & $100(100 \%)$ & 1627 & $(100 \%)$ \\
\hline \multicolumn{6}{|l|}{ Metropolitan Size: } \\
\hline Over 500,000 & $44(47 \%)$ & $265(18 \%)$ & $21(21 \%)$ & 330 & $(20 \%)$ \\
\hline $50,000-500,000$ & $26(28 \%)$ & $488(34 \%)$ & $28(28 \%)$ & 542 & $(33 \%)$ \\
\hline Town, under 50,000 & $22(24 \%)$ & $610(42 \%)$ & $41(41 \%)$ & 672 & $(41 \%)$ \\
\hline Rural area & $1 \quad(1 \%)$ & $72 \quad(5 \%)$ & $11(11 \%)$ & 84 & $(5 \%)$ \\
\hline Totala & $92(100 \%)$ & $1436(99 \%)$ & $100(101 \%)$ & 1627 & $(99 \%)$ \\
\hline \multicolumn{6}{|l|}{ Institutional Auspices: } \\
\hline Public & $70(76 \%)$ & $914(64 \%)$ & $76(76 \%)$ & 1060 & $(65 \%)$ \\
\hline Independent & $21(23 \%)$ & $334(23 \%)$ & $13(13 \%)$ & 367 & $(23 \%)$ \\
\hline Religious & $1 \quad(2 \%)$ & $185(13 \%)$ & $11 \quad(11 \%)$ & 197 & $(12 \%)$ \\
\hline Totala & $92(101 \%)$ & $1431(100 \%)$ & $100(100 \%)$ & 1623 & $(100 \%)$ \\
\hline
\end{tabular}

Chi-Square (Faculty Size by Race/Ethnicity) $=22.5, \mathrm{p}<.001$

Chi-Square (Metropolitan Size by Race/Ethnicity) $=53.0, \mathrm{p}<.001$

Chi-Square (Auspices by Race/Ethnicity) $=17.1, \mathrm{p}<.001$

aPercentages may not add to 100 due to rounding. 
other faculty to work in institutions under religious auspices. The same patterns appear at the departmental level (data not presented in tables): 42 percent of sociology departments in cities over 500,000 have at least one black sociologist, but only 25 percent of those in smaller cities and 14 percent of those in towns. Two-thirds of the largest departments-those with 20 or more members-have a black sociologist, but only 12 percent of small departments (10 or fewer) do. Black sociologists are found in 31 percent of public institutions, in 20 percent of independent institutions, but in only 2 percent of religious institutions.

In multivariate analyses, these same factors predict which departments will have black sociologists, but their effects are overshadowed by an even stronger factor, the relative size of the black undergraduate student population. Table 4 presents the results of two logistic regressions of the presence (coded 1) or absence (coded 0) of a black faculty member in the department." The first includes the undergraduate percent black as a predictor, and the second omits that variable. Institutions with a higher proportion of black students tend, not surprisingly, to have black faculty, but the logarithmic form of the relationship is noteworthy." As the relative size of the black student body increases, the odds of having a black sociologist on the faculty grow sharply at first but at a steadily decelerating rate. This means that institutions with near majorities of black students are only marginally more likely to emply black sociologists than those with smaller, though still substantial, black student minorities on campus. Larger and more prestigious institutions, those relying more on governmental revenues (a factor closely related to public auspices)," those with growing sociology faculties, and departments chaired by white men, all are more likely to have black sociology faculty. Controlling for other factors, southern institutions are less likely than those in the Northeast to have black sociologists, as are departments with high faculty turnover rates.

Other effects depend on whether or not the size of the black student population is controlled. Institutions in large metropolitan areas generally have proportionally more black students, which explains why they also have greater odds of having black faculty. It is not simply that these institutions also have larger faculties, hence more faculty positions to fill, because the equations control for institutional and departmental size. In a related pattern, departments in the West have lower odds of containing black sociologists, apparently because these institutions have smaller populations of black students. A weak research orientation, sizable fractions of faculty positions at the instructor or lecturer level, an established Black Studies program, and robust per student budgets all increase modestly the odds that a black sociologist will be among the faculty.

Political-economy variables are weaker predictors of the percentage of sociology faculty positions held by African-Americans (Table 5), but the effects are generally consistent with those that explain the sheer presence of at least one 
TABLE 4. Logistic Regression: Political Economy Variables Predicting the Presence of Black Faculty within Departments of Sociology in 1984, Excluding Majority Black Institutions ( $\mathrm{N}=220$ Departments)

\begin{tabular}{|c|c|c|c|c|}
\hline$\underline{\text { Predictor Variables }}$ & \multicolumn{2}{|c|}{$\begin{array}{l}\text { Including } \\
\text { Undergraduate }\end{array}$} & $\begin{array}{l}\text { Exclu } \\
\text { Undergr } \\
\text { Percent }\end{array}$ & $\begin{array}{l}\text { ing } \\
\text { duate } \\
\text { Black }\end{array}$ \\
\hline Internal Economy & & & & \\
\hline Per Student Annual & & & & \\
\hline Expenditures (natural log) & .338 & $(.140) \mathrm{a}$ & $635+$ & $(.264) \mathrm{a}$ \\
\hline Real Growth in Sociology & & & & \\
\hline Faculty $1975-84$ & $037+$ & $(.183)$ & $.030+$ & $(.149)$ \\
\hline Percent Sociology Faculty & & & & \\
\hline Turnover $1979-84$ & $-.014+$ & $(-.302)$ & $-.013+$ & $(-.274)$ \\
\hline Institutional Prestige/Selectivity & $.515+$ & $(.273)$ & .331 & $(.177)$ \\
\hline Institutional \& Departmental & & & & \\
\hline Research Context & -.220 & $(-.117)$ & $-.303+$ & $(-.162)$ \\
\hline Institutional Size & $861^{* *}$ & $(.458)$ & $.758 * *$ & $(.402)$ \\
\hline $\begin{array}{l}\text { Sociology Faculty: Percent } \\
\text { Instructors/Lecturers }\end{array}$ & .024 & $(.121)$ & $038+$ & $(.192)$ \\
\hline $\begin{array}{l}\text { Black Studies Program Exists } \\
(\mathrm{Y}=1 ; \mathrm{N}=0)\end{array}$ & .728 & $(.145)$ & $916+$ & $(.183)$ \\
\hline External Economy & & & & \\
\hline Metropolitan Area (over & & & & \\
\hline 500,000$)(\mathrm{Y}=1 ; N=0)$ & .822 & $(.151)$ & $1.898 * *$ & $(.353)$ \\
\hline $\begin{array}{l}\text { City }(50,000-500,000)(Y=1 \\
N=O)\end{array}$ & .782 & $(.187)$ & $.772+$ & $(.185)$ \\
\hline Midwest Region $(\mathrm{Y}=1$ & & & & \\
\hline$N=0)$ & -.370 & $(-.089)$ & -.609 & $(-.146)$ \\
\hline $\begin{array}{l}\text { Southern Region }(\mathrm{Y}=1 \\
N=O)\end{array}$ & $-1.835 * *$ & $(-.473)$ & $-1.581 *$ & $(-.408)$ \\
\hline $\begin{array}{l}\text { Western Region }(\mathrm{Y}=1 \\
N=O)\end{array}$ & -.756 & $(-.137)$ & $-1.712 *$ & $(-.309)$ \\
\hline Internal Polity & & & & \\
\hline $\begin{array}{l}\text { White Male Sociology Dept. } \\
\text { Chair }(\mathrm{Y}=1 ; N=O)\end{array}$ & $2.289^{*}$ & $(.490)$ & $2.763 * *$ & $(.589)$ \\
\hline $\begin{array}{l}\text { Undergraduates: Percent Black } \\
\text { (natural log) }\end{array}$ & $1.191 * * *$ & $(.592)$ & & \\
\hline External Polity & & & & \\
\hline $\begin{array}{l}\text { Government Funding/ } \\
\text { Expenditures }\end{array}$ & $.020+$ & $(.281)$ & $.024^{*}$ & $(.341)$ \\
\hline Intercept & -8.294 & & -9.104 & \\
\hline Chi-square (d.f. in parentheses) & 80.9 & $(16)$ & 67.2 & $(15)$ \\
\hline
\end{tabular}

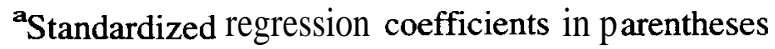

Note: One-tailed tests: $+\mathrm{P}<.10 ; * \mathrm{P}<.05 ; * * \mathrm{P}<.01 ; * * * \mathrm{P}<.001$ 
TABLE 5. OLS Regression: Political Economy Variables Predicting the Proportional Representation' of Black Faculty within Departments of Sociology in 1984, Excluding Majority Black Institutions $(\mathrm{N}=220)$

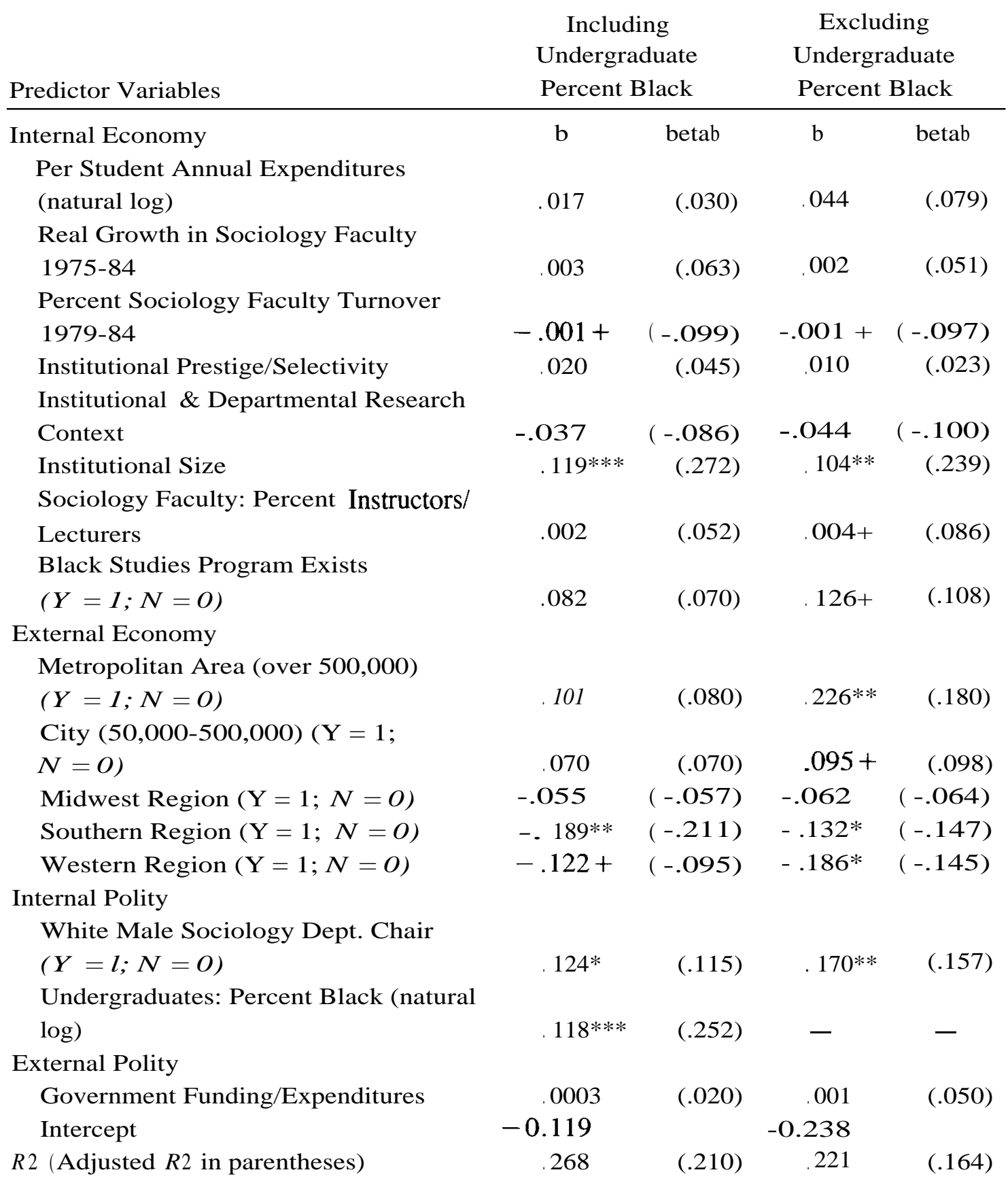

aThe dependent variable is the natural log of the black percentage of faculty positions. 'Standardized regression coefficients in parentheses $+P<.10 ; * P<.05 ; * * P<.01 ; * * * P<.001$ (one-tailed tests) 
black sociologist. Again, the racial composition of undergraduates is an especially potent predictor, linking black sociologists' share of faculty positions with the relative size of the black student population. There are, however, five factors that are predictors of the presence/absence of black sociologists, but not the proportional representation of black faculty: faculty growth and turnover, prestige and research orientation, and reliance on governmental funding. The similarities among the predictors of black faculty's absolute and proportional representation derive in part from the complete absence of African-American sociologists in four of every five departments. Differences in African-Americans' share of faculty positions center on contrasts between departments that have any black faculty at all versus those with none. It is necessary then to restrict attention to departments with at least one black sociologist to specify more exactly those that have substantial numbers and proportions of black faculty.

\section{Solos and Tokenism}

Within academic sociology African-Americans rarely constitute the "critical mass" that Pettigrew and Martin (1987) maintain is necessary to mitigate the negative effects of solo status. Few departments meet their criteria of absolute (more than two representatives) and proportional (greater than 20 percent) representation, both seemingly modest thresholds. In nearly half (47 percent) of the departments with black sociologists, the black faculty members are solos. Only 15 percent of these departments have three or more black sociologists, and less than a third of them have departmental faculties where at least one in five of the members is African-American. Table 6 analyzes variations in the absolute number of black sociologists and in the black percentage of faculty positions within "integrated" departments, that is, those with at least one black faculty member. Internal political factors are significant predictors of these outcomes. The number and proportion of black sociologists is higher in institutions with proportionally larger black student populations, but is smaller in integrated departments chaired by white men. Other factors influence critical mass in contradictory ways, simultaneously increasing the absolute number of black sociologists while reducing their proportional representation (organizational size, metropolitan location), or vice versa (prestige, location outside the Northeast).

\section{Racial Disparities in Academic Rank}

Black sociologists typically hold lower academic rank than non-Hispanic whites or other minority groups (Table 7). At the individual level, black faculty are most likely to be assistant professors, while the modal rank for others is full professor. About half of black faculty hold the advanced ranks that usually 
TABLE 6. OLS Regression: Political Economy Variables Predicting the Absolute and Proportional Representation of Black Faculty in Sociology Departments with Black Faculty in $1984(\mathrm{~N}=56)$

\begin{tabular}{|c|c|c|c|c|}
\hline \multirow{2}{*}{$\frac{\text { Predictor Variables }}{\text { Internal Economy }}$} & \multicolumn{2}{|c|}{$\begin{array}{l}\text { Number of Black } \\
\text { Sociologists }\end{array}$} & \multicolumn{2}{|c|}{$\begin{array}{l}\text { Sociology Faculty- } \\
\text { Percent Black } \\
\text { (natural log) }\end{array}$} \\
\hline & $\mathrm{b}$ & betaa & $\mathrm{b}$ & betaa \\
\hline $\begin{array}{l}\text { Per Student Annual Expenditures } \\
\text { (natural } \log \text { ) }\end{array}$ & 225 & $(.097)$ & $-10.416 * *$ & $(-.273)$ \\
\hline $\begin{array}{l}\text { Real Growth in Sociology Faculty } \\
1975-84\end{array}$ & -.002 & $(-.016)$ & .093 & $(.044)$ \\
\hline $\begin{array}{l}\text { Percent Sociology Faculty Turnover } \\
1979-84\end{array}$ & -.001 & $(-.019)$ & .059 & $(.047)$ \\
\hline $\begin{array}{l}\text { Institutional Prestige/Selectivity } \\
\text { Institutional \& Departmental }\end{array}$ & $-.488+$ & $(-.324)$ & $5.387^{*}$ & $(.218)$ \\
\hline Research Context & -.031 & $(-.025)$ & .687 & $(.034)$ \\
\hline Institutional Size & $.476^{*}$ & $(.357)$ & $-3.725 *$ & $(-.170)$ \\
\hline $\begin{array}{l}\text { Sociology Faculty: Percent } \\
\text { Instructors/Lecturers }\end{array}$ & $-.058 * *$ & $(-.308)$ & -.011 & $(-.003)$ \\
\hline $\begin{array}{l}\text { Black Studies Program Exists } \\
(Y=1 ; N=0)\end{array}$ & 147 & $(.043)$ & -3.433 & $(-.061)$ \\
\hline External Economy & & & & \\
\hline $\begin{array}{l}\text { Metropolitan Area (over 500,000) } \\
(Y=1 ; N=0)\end{array}$ & $1.232^{*}$ & $(.351)$ & $-6.622+$ & $(-.115)$ \\
\hline $\begin{array}{l}\text { City }(50,000-500,000)(\mathrm{Y}=1 \\
N=0)\end{array}$ & $1.148 *$ & $(.330)$ & 4.089 & $(.071)$ \\
\hline Midwest Region $(\mathrm{Y}=1 ; N=0)$ & $-.869 *$ & $(-.236)$ & $9.286 *$ & $(.154)$ \\
\hline Southern Region $(\mathrm{Y}=1 ; N=0)$ & $-1.198 *$ & $(-.350)$ & $10.179 *$ & $(.181)$ \\
\hline Western Region $(\mathrm{Y}=1 ; N=0)$ & $-1.290 *$ & $(-.264)$ & $12.571 *$ & $(.157)$ \\
\hline Internal Polity & & & & \\
\hline $\begin{array}{l}\text { White Male Sociology Dept. Chair } \\
(Y=1 ; N=0)\end{array}$ & $-2.230 * *$ & $(-.536)$ & $-30.016 * * *$ & $(-.440)$ \\
\hline $\begin{array}{l}\text { Undergraduates: Percent Black } \\
\text { (natural log) }\end{array}$ & $.577^{*}$ & $(.373)$ & $13.016^{* * *}$ & $(.512)$ \\
\hline External Polity & & & & \\
\hline Government Funding/Expenditures & -.012 & $(-.190)$ & -.058 & $(-.058)$ \\
\hline Intercept & 1.433 & & 87.633 & \\
\hline$R 2$ (Adjusted $R 2$ in parentheses) & .673 & $(.539)$ & 905 & $(.865)$ \\
\hline
\end{tabular}

${ }^{\mathrm{a}}$ Standardized regression coefficients in parentheses

$+P<.10 ; * P<.05 ;{ }^{* *} P<.01 ; * * * P<.001$ (one-tailed tests) 
TABLE 7. Academic Rank of Sociology Faculty in 1984 by Race or Ethnicity

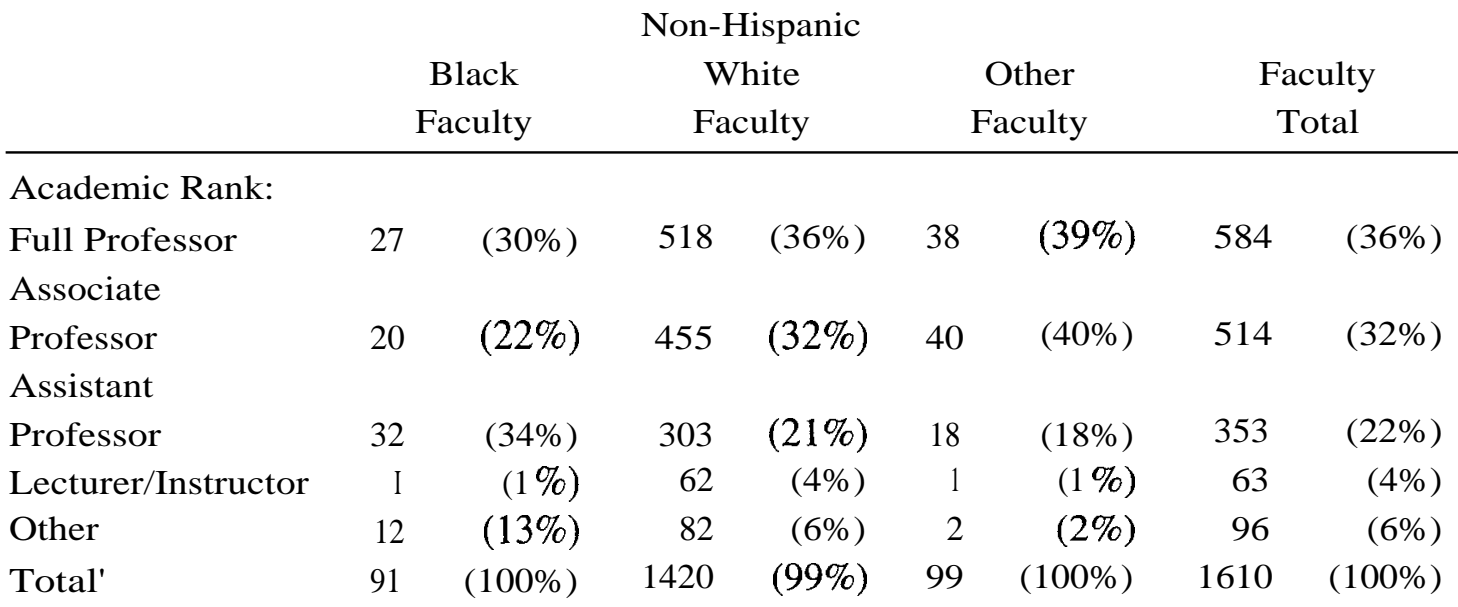

Chi-Square (Academic Rank by Race/Ethnicity) $=29.4, \mathrm{p}<.001$

aPercentages may not add to 100 due to rounding.

imply tenure-full or associate professor-while more than two-thirds of nonHispanic whites and over three-quarters of other minorities enjoy those more secure positions. Although the absolute number is small, a substantial minority of black sociologists-far more, proportionally, than other groups-fall into an unclassified category of academic rank as visiting, adjunct, or emeriti professors. Racial discrepancies in academic rank appear at the departmental as well as the individual level (data not presented in tables). In 75 percent of integrated departments, African-Americans occupy lower academic ranks, on average, than other sociology faculty do."

It is arguable that racial differences in academic rank reflect relatively more recent entry into academic positions by black sociologists. If so, rank disparities could narrow in time as black professors advance to tenure and promotion decisions. This explanation cannot be ruled out entirely with the data available for this study, which for individual faculty include neither the duration of academic work experience nor elapsed time from the receipt of the doctorate. But we can control for the proportion of black faculty who have joined the department within the last five years, a group that would normally encompass all new tenure-track faculty. If the introduction of this variable fails to mitigate institutional effects on the size of racial disparities in academic rank, it is doubtful that these effects can be attributed primarily to African-Americans' earlier career stages.

The final multivariate test of the political-economy model introduces this control for the percentage of black faculty who were hired in the department within the previous five years to predict the degree of segregation in academic rank along racial lines (Table 8). All other factors are overshadowed by the 
TABLE 8. OLS Regression of 1984 Index of Academic Rank Segregation by Race $(\mathrm{H})$, in Departments with Both Black and Nonblack Faculty $(\mathrm{N}=54)$

Predictor Variables

\begin{tabular}{|c|c|c|}
\hline Percent of Black Faculty Hired Within 5 Years & 001 & $(.109) \mathrm{a}$ \\
\hline \multicolumn{3}{|l|}{ Internal Economy } \\
\hline Per Student Annual Expenditures (natural log) & $-.233 *$ & $(-.280)=$ \\
\hline Real Growth in Sociology Faculty $1975-84$ & .002 & $(.041)$ \\
\hline Percent Sociology Faculty Turnover 1979-84 & -.003 & $(-.094)$ \\
\hline Institutional Prestige/Selectivity & $-.173 *$ & $(-.321)$ \\
\hline Institutional \& Departmental Research Context & $121^{* *}$ & $(.273)$ \\
\hline Institutional Size & .036 & $(.075)$ \\
\hline Sociol. Faculty: Percent Instructors/Lecturers & -.004 & $(-.060)$ \\
\hline Black Studies Program Exists $(\mathrm{Y}=1 ; N=O)$ & .099 & $(.081)$ \\
\hline \multicolumn{3}{|l|}{ External Economy } \\
\hline Metropolitan Area (over 500,000) $(\mathrm{Y}=1 ; N=O)$ & .125 & $(.100)$ \\
\hline City $(50,000-500,000)(\mathrm{Y}=1 ; N=O)$ & -.137 & $(-.110)$ \\
\hline Midwest Region $(\mathrm{Y}=1 ; N=O)$ & .059 & $(.045)$ \\
\hline Southern Region $(\mathrm{Y}=1 ; N=O)$ & .080 & $(.065)$ \\
\hline Western Region $(\mathrm{Y}=1 ; N=O)$ & .094 & $(.054)$ \\
\hline \multicolumn{3}{|l|}{ Internal Polity } \\
\hline White Male Sociology Dept. Chair $(\mathrm{Y}=1 ; N=O)$ & $439 *$ & $(.295)$ \\
\hline Undergraduates: Percent Black (natural log) & .006 & $(.011)$ \\
\hline \multicolumn{3}{|l|}{ External Polity } \\
\hline Government Funding/Expenditures & $-.018 * * *$ & $(-.819)$ \\
\hline Intercept & 2.070 & \\
\hline$R 2$ (Adjusted $R 2$ in parentheses) & 800 & $(.711)$ \\
\hline
\end{tabular}

degree of reliance on governmental sources of revenue, which tends to minimize racial disparities in academic rank. This is by far the most influential factor in an equation that explains over 70 percent of the variation in the index of rank segregation. Rank is also distributed more equally in the most prestigious and financially robust institutions. On the other hand, discrepancies in the allocation of rank are more pronounced in research-oriented departments, and those chaired by white males. The geographic factors in the external economy have no significant effects on rank segregation when dependence on governmental revenue is controlled. When this potent effect is removed from the equation, however, institutions in large cities manifest markedly greater disparities in academic rank and institutions in the South register lower rank segregation scores than those in the Northeast (results not presented in tables). 


\section{Political Economy Effects}

The results in Tables 5, 6, and 8 implicate each of the elements of the political economy framework as influential in some facet of the incorporation of black sociologists into academia. Although these forces do not always operate in the expected way, they form a pattern of effects from which some conclusions can be derived. To make sense of the patterns, it is necessary to examine how each organizational factor relates to different facets of the integration of black faculty members.

There is no evidence that "slack" financial resources influence outcomes for African-American faculty only in the direction dictated by internal political forces, as suggested by the first hypothesis (H1). No interaction effects were found. Instead, financially robust institutions appear more likely to recruit black sociologists, in part because they have somewhat larger black student populations. Black faculty in these institutions occupy smaller proportions of faculty positions within the department than in other integrated departments, but they also enjoy academic rank more nearly equivalent to their nonblack colleagues.

As hypothesized, expanding faculties have slightly higher odds of having black representation (H2), but, unexpectedly, high faculty turnover lowers those odds appreciably. Further, as with the impact of slack financial resources, these effects were not linked to political forces as hypothesized. All faculty openings are apparently not alike in creating opportunities for black faculty. It seems to be easier to recruit black sociologists if the position is created through growth rather than through turnover. Although not addressed here, high turnover rates may, of course, involve losses of black as well as white faculty. If black faculty were relative newcomers, this may have been important in the period investigated, the early 1980s, when sociology faculties contracted nationwide. The negative impact of high turnover on black faculty representation is also consistent with the "musical chairs" hypothesis if we assume that black sociologists were leaving these departments to take up positions at very select institutions with small odds of falling into our national sample of departments. In any case, faculty expansion and turnover were, as predicted, unrelated to the proportional representation of black faculty and had no impact on racial disparities in academic rank (H3).

Contrary to expectations, prestigious institutions have better odds of having a black faculty member present, once one accounts for their typically smaller black student populations (H4). Among racially integrated departments, the more prestigious have fewer black faculty in absolute numbers, but a higher proportion of their faculty are black, and, as expected, they have more balanced racial allocations of academic rank.

Although institutional prestige and research emphasis are often linked, ex- 
pectations regarding the inhospitableness of research-oriented climates for black faculty are generally supported (H5). Institutions with stronger research climates are less likely to have any black sociologists, and those that do have larger racial gaps in the allocation of academic rank.

As expected, large institutions do have better representation of black faculty (H6), both in terms of having any black sociologists present, and multiple black faculty as well. Two other findings suggest that this is the result of the larger numbers of faculty opportunities rather than the hypothesized tendency toward formalization in personnel actions. Size was unrelated to the degree of racial segregation in academic rank, and black sociologists in large institutions occupied proportionally fewer faculty positions than those in smaller institutions.

The effects of labor market segmentation partially confirmed initial expectations. Institutions with Black Studies programs and those with a high proportion of faculty at the instructor or lecturer level are more likely to have black sociologists (H7), in part because they are also more likely to have sizable populations of black students. But these conditions are unrelated to the degree of racial disparity in academic rank.

Regional and metropolitan variations are strongly implicated in the presence of black sociologists in academia (H8). A department is considerably more likely to have a black sociology faculty member if it is located in a large metropolitan area, where large black student populations tend to be present. Among racially integrated faculties, those in large cities tend more often to have multiple black faculty and less inequity in academic rank. Departments in the Northeast are most likely to have a black sociologist, and they have the largest number (though the smallest percentage) of black sociologists. Controlling for other factors, racial discrepancies in rank are unrelated to geographical location.

Perhaps the most surprising finding is that departments chaired by white men are more likely to have a black faculty presence than those chaired by women or minority group members. But one cannot tell from the data whether this reflects trade-offs in recruiting some underrepresented groups at the cost of others, differential patterns of employment opportunities, or differences in the attractiveness of the departments to potential black recruits. In integrated departments, the findings turned out more as expected (H9): Those with white male chairpeople had fewer black faculty, both in absolute numbers and proportionally, and larger discrepancies in academic rank as well.

The odds that an institution will employ black sociologists are closely linked to the relative size of the black student population $(\mathrm{H10})$, which also relates directly to the proportion of faculty positions held by African-Americans. It would be very useful to know the extent to which this is a "push" generated by perceived desires or demands of black students for black faculty, or a "pull" that attracts black faculty recruits. Whatever the source of this influence, it 
appears to be limited to representational matters, and has no effect on the degree of racial disparity in academic rank.

Black sociologists are found more often in public than private institutions, and only rarely in those under religious auspices (H11). A closely related factor-reliance on governmental revenues-increases the odds that a black sociologist will be present, and among racially integrated faculties, decreases the extent of racial discrepancies in academic rank.

\section{CONCLUSIONS AND IMPLICATIONS}

Among the patterns that may be discerned in the disparate findings is a distinguishing hallmark of black faculty presence: a context of large scale envelops the one in every five departments with black sociologists on their faculty. These tend to have large or expanding departmental faculties, robust finances, large enrollments, sizable proportions of black students, and a large surrounding metropolis. Apparently, "big is better" in recruiting black faculty for several reasons: more opportunities for faculty appointments; the ability to absorb black faculty without disrupting existing power relations among the faculty; the attractions of a school and community environment where opportunities to interact with other African-Americans are plentiful; and perhaps the ability to offer a better salary package.

Yet the factors that promote the presence of black faculty are not always linked to work environments that provide substantial numerical clout in faculty decision making, or minimal racial disparities in academic rank. The advantages of large size increase the odds that multiple black sociologists will be hired in a department, but also dilute the power they can wield. This suggests something of a dilemma for black sociologists in search of critical mass, both in numbers and proportions. They may be unable to claim a numerically potent role in faculty decision making within the departments where they are most likely to avoid solo status. Compounding the dilemma is the absence of links between racial equality in academic rank and most of the factors associated with large scale. Departments that offer a core of black colleagues may not provide especially favorable conditions for tenure and promotion to advanced ranks. Instead, where racial gaps in academic rank are narrowest, there is a hint of the carrot and stick at work. Smaller discrepancies in rank within more selective and financially robust institutions may reflect their ability to attract recognized black faculty with established scholarly credentials. Outside pressure on the institution, in the form of dependence on governmental revenues, appears to be an even more potent catalyst for reducing racial disparities in ranks. These very suggestive findings need to be replicated, however, controlling more directly for individual-level differences in the timing of black and white faculty careers. 
Organizational variations in the representation and status of black sociologists within academe reflect complex interactions between the employment preferences of potential black candidates, and institutional contexts that are more or less active in recruiting and retaining them. Further research into black scholars' view of the academy will be required to disentangle these individual and institutional forces. Even if key institutional factors are found to be crucial to the successful incorporation of black faculty, not all may be manipulable to design. This bears on the likely success of various suggested remedies to improve the representation and work conditions of black faculty members. Many proposals focus on redressing problems of supply, calling for more pre- and postdoctoral financial support for minority students (Blackwell, 1988); consortia of predominantly black with predominantly white institutions (Haggin, 1989); early identification and recruitment of doctoral students (Wilson, 1987); and recruitment from the faculty of black colleges and attendees at conferences of black educators (Harris, 1989). With more than twice as many institutions as there are black sociologists to staff them, problems of supply will continue to dominate issues of black faculty representation. But this study suggests that simply increasing the number of black scholars may be insufficient to attract black faculty to smaller institutional settings, rural areas, and colleges without sizable black populations among students and/or the local community. An expanded supply of black faculty may further enlarge black representation at large metropolitan campuses and a few southern institutions where most black faculty now reside. Moreover, the lack of overlap in the predictors of black faculty recruitment and of racial equality in the distribution of academic rank suggests that more than one set of institutional forces may be required to simultaneously recruit, retain, and equitably reward black faculty. 
APPENDIX. Pearson Correlation Coefficients, Means, and Standard Deviations of Model Variables

\begin{tabular}{|c|c|c|c|c|c|c|c|c|c|c|}
\hline & (1) & (2) & (3) & (4) & (5) & (6) & (7) & (8) & (9) & (10) \\
\hline \multicolumn{11}{|l|}{ (1) Number } \\
\hline $\begin{array}{l}\text { of Black } \\
\text { Faculty } \\
\text { (collapsed) }\end{array}$ & 1.00 & & & & & & & & & \\
\hline (2) Faculty & & & & & & & & & & \\
\hline Percent & & & & & & & & & & \\
\hline $\begin{array}{l}\text { Black (natu- } \\
\text { ral log) }\end{array}$ & $.91 * * *$ & 1.00 & & & & & & & & \\
\hline \multicolumn{11}{|l|}{$\begin{array}{l}\text { (3) Rank } \\
\text { Segregation }\end{array}$} \\
\hline Index & $-.71 * * *$ & $-.79 * * *$ & 1.00 & & & & & & & \\
\hline $\begin{array}{l}\text { (4) Soci- } \\
\text { ology Fac- } \\
\text { ulty Growth }\end{array}$ & & & & & & & & & & \\
\hline $\begin{array}{l}\text { Rate } \\
\text { (5) Soci- } \\
\text { ology } \\
\text { Faculty }\end{array}$ & -.01 & -.05 & -.03 & 1.00 & & & & & & \\
\hline $\begin{array}{l}\text { Turnover } \\
\text { (6) Institu- }\end{array}$ & -.10 & -.09 & .09 & -.04 & 1.00 & & & & & \\
\hline $\begin{array}{l}\text { tional Size } \\
\text { (7) Institu- } \\
\text { tional Pres- } \\
\text { tige/ }\end{array}$ & $.42^{* * *}$ & $26^{* * *}$ & $-.29 * * *$ & .03 & $-.24 * * *$ & 1.00 & & & & \\
\hline $\begin{array}{l}\text { Selectivity } \\
\text { (8) Soci- } \\
\text { ology: Per- } \\
\text { cent } \\
\text { Instructors/ }\end{array}$ & .01 & .03 & -.07 & .03 & & & 1.00 & & & \\
\hline $\begin{array}{l}\text { Lecturers } \\
\text { (9) Black }\end{array}$ & -.06 & -.00 & .02 & -.04 & -.03 & .01 & $-.24 * * *$ & 1.00 & & \\
\hline $\begin{array}{l}\text { Studies } \\
\text { Program }\end{array}$ & & & & & & & & & & \\
\hline $\begin{array}{l}(\mathrm{Y}=1 ; \\
\mathrm{N}=0) \\
(10) \text { Per }\end{array}$ & $21^{* *}$ & $.14^{*}$ & & .09 & .002 & $.33 * * *$ & $43 * * *$ & -.11 & 1.00 & \\
\hline Student & & & & & & & & & & \\
\hline $\begin{array}{l}\text { Annual Ex- } \\
\text { penditures }\end{array}$ & & & & & & & & & & \\
\hline (nat. log) & -.02 & -.02 & -.07 & $-34 * * *$ & $.15^{*}$ & $-.16^{*}$ & $45^{* * * *}$ & -.07 & $.38 * * *$ & 1.00 \\
\hline
\end{tabular}


(11) White

Male Soci-

ology Chair

$(\mathrm{Y}=1$;

$\mathrm{N}=0$ )

(12) Under-

graduates:

Percent

Black (nat.

$\log )$

$.43 * * * \quad .48 * * \quad-.42 * * * \quad-.06$

$.07 \quad .06$

.04

$10 \quad-.02$

$.07 \quad-.05$

1.00

(13) Re-

search

Context

$\begin{array}{llllll}.04 & -.03 & -.01 & -.34 * * * & -.08 & \end{array}$

(14) Metro

Area (over

500,000

( $\mathrm{Y}=1$;

$N=O)$
$(15)$ City

$$
.29 * * * \quad .25 * * * \quad-.07
$$

$.05 \quad-.01$

$.17^{*} \quad-.01 \quad-.11$

.01

$-.04 \quad-.02$

$.30 * * * \quad-.002 \quad 1.00$

(50,000-

$500,000)$

( $\mathrm{Y}=1$;

$N=O$ )

.08

.04

$-. \mathrm{O}$

$-.15 *$

$-.20 * *$

$.20 * * \quad-.06$

$.20 * * \quad .09$

.07

$.01 \quad-.04$

$-.24 * * *$

west Region

( $\mathrm{Y}=1$;

$N=O)$

(17) South-

em Region

( $\mathrm{Y}=1$;

$N=O$ )

$.08 \quad-.002$

.002

$.06-.25^{* * *} \quad .07$

07

$.07 \quad-.01$

$.02 \quad .02$

.02

$.07 \quad-.07$

$.04 \quad .12$

$.08 \quad 1.00$

(18) West-

ern Region

( $\mathrm{Y}=1$;

$\begin{array}{lll}.002 & .02 \quad-.06\end{array}$

$.14 \times$

$-.17 * \quad-.06$

$-.27 * * *$

$\begin{array}{llll}.01 & -.20 * * & -.23 * * * & -\mathrm{At}\end{array}$

$.31^{* * *} \quad-.04 \quad-.10$

$\begin{array}{lll}-.09 & -.44 * * * & 1.00\end{array}$

$-04-04$

(19) Gov-

ernment

Funding/Ex-

penditures

$\begin{array}{llll}.27 * * * & .25^{* * *} & -.39 * * * & .02 \\ (1) & (2) & (3) & (4) \\ 0.33 & 0.24 & 0.85 & -0.59\end{array}$

$-.14^{*}$

$.15^{*} \quad-.03$

.03

.07

$-.002$

$-.001-.20 * *$

$.07 \quad .12$

$\begin{array}{llll}.09 & -.21 * * * & -.29 * * * & 1.00\end{array}$

Mean

0.33

Standard

(0.74

$\begin{array}{lll}0.24 & 0.85 & -0.59\end{array}$

$-.35 * * *$

$.52 * * * \quad-.37 * * *$

.05
$(8)$
3.72

.03
$(9)$
0.15

$\begin{array}{cccccccccc}-.30^{* * *} & -.20 * * & .12 & .09 & -.04 & .13 & -.05 & .15 * & .12 & 1.00 \\ (10) & (11) & (12) & (13) & (14) & (15) & (16) & (17) & (18) & (19) \\ 6.75 & 0.79 & 1.50 & 0.0 & 0.15 & 0.25 & 0.25 & 0.37 & 0.12 & 27.97 \\ & & & & & & & & & \\ \mathbf{0 . 7 5} & \mathbf{0 . 4 0} & 1 . \underline{\mathbf{4}} & 0.96 & 0.35 & 0.43 & 0.43 & \underline{0.48} & 0.33 & 26.90\end{array}$

$* \mathrm{P}<.05 ; * * \mathrm{P}<.01 ; * * * \mathrm{P}<.001$ (Two-tailed tests) 


\section{NOTES}

1. In something of a vicious circle, the declining presence of black professors appears to be quite consequential for black students, because they may help these students cultivate and maintain racial identity, awareness, and pride within predominantly white environments. Moreover, they may more effectively communicate knowledge to black students (Nickson, 1982) and may improve their educational outcomes (Fleming, 1984).

2. Growing proportional representation may not enhance a minority's power monotonically, and discrimination may actually intensify. Research on underrepresented groups in various settings suggests that growth in proportional representation may increase harassment and negative attitudes (Deaux and Ullman, 1983; Fossett and Kiecolt, 1989; Gruber and Bjorn, 1982), or may weaken the impetus for further increasing the group's participation (Kulis and Miller, 1989).

3. From 1978 to 1985 , the total number of new doctorates in the social sciences declined from 3,008 to 2,607, while those awarded'to blacks increased from 123 to 150 . As the overall pool shrank, the black percentage of new doctorates increased from 4.0 to 5.7 (National Science Foundation, 1990).

4. The states were AK, AZ, CA, HA, ID, MT, NV, NM, OR, UT, WA, and WY.

5. Faculty at other ranks (e.g., unspecified "adjunct," visiting, and emeriti professors) were excluded from this portion of the analysis because of small numbers and lack of comparability across departments.

6. Applied in this context, the Theil and Finizza (1971) index is defined as:

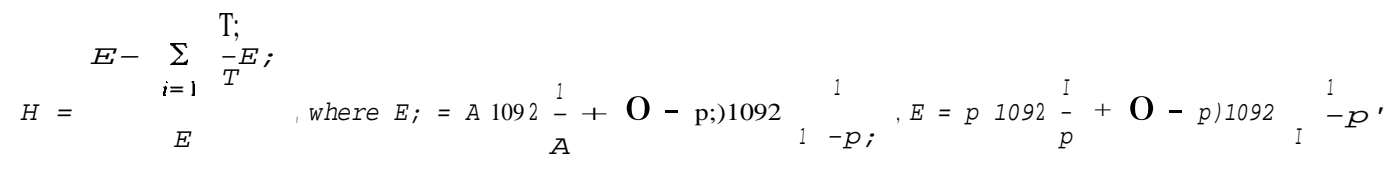

where $\mathrm{N}$ is the number of academic ranks in the department, $\mathrm{T}$; is the number of faculty at the $i^{\text {th }}$ rank, $\mathrm{T}$ is the total number of faculty within the department, $p_{i}$ is the proportion black at the $i^{\text {th }}$ rank, and $\mathrm{p}$ is the proportion black within the departmental faculty as a whole. In most departments with both black and nonblack faculty, black faculty typically held lower academic ranks than their counterparts. As the disparities in rank grow, so does the magnitude of this index. But in 10 departments black faculty occupied higher average rank. Rather than exclude these from the analysis, or worse, treat them the same as those where racial disparities favored whites, index scores for these 10 departments were multiplied by - 1 to produce negative values. The modified index forms a continuum: large negative values when black faculty outrank others, and high positive values when they occupy lower ranks. Zero indicates that black and nonblack faculty are identically distributed across academic ranks.

7. Like other measures of segregation, $\mathrm{H}$ is unstable when calculated for extremely small groups. In very small departments, moving a single individual from one academic rank to another can drastically alter the index score. To ensure that our results were not artifacts of these instabilities, regression analyses were repeated after weighting each case by the size of its Sociology faculty, thus deemphasizing the influence of very small departments on the regression coefficients. This did not change the direction or general magnitude of the results reported in Table 8 .

8. This study used SAT scores when available. For the dozen schools that reported only ACT scores for entering freshmen, average ACT scores were standardized and converted to an estimated SAT score (Astin, 1971). For better or worse, SAT/ACT scores are used to screen applicants, resulting in a very large inverse correlation between average SAT/ACT scores for entering freshmen and the proportion of freshman applicants who are offered admission. If the 
level of demand for educational services is at all related to the quality of the offering, then higher-quality undergraduate programs will attract more applicants and will be more successful in enrolling students with high aptitude scores than institutions with programs of lesser quality.

9. The number of Hispanic (28) and Native American (9) faculty is too small to analyze separately, so they have been combined here with Asian-American sociologists, who comprise 62 percent of the nonblack minority category.

10. From a strictly statistical vantage point this figure is intermediate to those that would result it black sociologists were distributed to the nation's departments under conditions of extreme dispersion versus segregation. If the 92 black sociologists in the sample were distributed as widely as possible among the 230 departments, only 40 percent of the departments would contain a black sociologist. On the other hand, if black faculty were completely segregated into all-black departments (assuming these departments were of average size), they would comprise only 5 percent of all departments, a figure equal to the proportional representation of AfricanAmericans among all sociology faculty.

11. These results exclude the sample's three majority black institutions, two of which are historically black colleges. Their unique histories and special missions set them apart from other institutions where the incorporation of blacks has been more problematic. When these schools are included in the analysis, the effect of the undergraduate percent black on the presence of black faculty is even more pronounced, and other effects are reduced in magnitude. Also of note is that the equations are presented without the interaction effects suggested by several hypotheses. Interaction terms were examined by multiplying in turn each of the political variables by "slack" in financial resources, faculty growth, and faculty turnover. None of these interactions achieved statistical significance.

12. The natural log transformation of the undergraduate percent black was employed because the variable was quite skewed, with few schools having majorities or near majorities of black students. The transformed variable provided a better fit to the data, as indicated by an improvement in explained variation in regression analyses.

13. In the full sample of institutions, public auspices is closely tied to the degree of dependence on governmental revenues $(r=.93)$, and the two variables cannot be entered into multivariate analyses without incurring distortions due to multicollinearity. This relationship is weaker among the smaller group of institutions that have at least one black sociology faculty member.

14. For these comparisons faculty at four academic ranks are assigned values as follows: full professor (4), associate professor (3), assistant professor (2), and lecturer or instructor (1). This is a conservative estimate of racial differences in rank because all faculty at miscellaneous "other" ranks-a group that is disproportionately black-are excluded from consideration.

\section{REFERENCES}

American Council on Education (1986). Minorities in Higher Education. Fifth Annual Status Report. Washington, DC: American Council on Education, Office of Minority Concerns.

American Council on Education (1989). Eighth A nnual Status Report on Minorities in Higher Education. Washington, DC: American Council on Education, Office of Minority Concerns.

Astin, Alexander W. (1971). Predicting Academic Performance in College. New York: Free Press.

Averitt, Richard T. (1968). The Dual Economy: The Dynamics of American Industry Structure. New York: Norton.

Bacon, A. (1974). Research in traditionally black schools. In Black Scholars in Higher 
Education in the 1970s, R. Johnson (ed.), pp. 153-158. Columbus, OH: ECCA Publications.

Bernard, Jessie (1964). A cademic Women. University Park, PA: Pennsylvania State University Press.

Blackburn, Robert T., and Young, Denise L. (1985). Faculty quality in black and white public colleges and universities in selected southern states: 1954-1980. Teacher's College Record 86(Summer): 593-613.

Blackwell, James E. (1988). Faculty issues: The impact on minorities. Review of Higher Education 11 (Summer): 417-434.

Blau, Peter M. (1973). The Organization of A cademic Work. New York: John Wiley.

Brazziel, William F. (1988). Road blocks to graduate school: Black Americans are not achieving parity. Educational Record 68-69(Fall-Winter): 108-115.

Breneman, David W., and Youn, Ted I. K. (1988). Academic Labor Markets and Careers. New York: Falmer Press.

Brown, Shirley Vining (1988). Increasing Minority Faculty: An Elusive Goal. Princeton, NJ: Graduate Record Examinations Board, Education Testing Service.

Caplow, Theodore, and McGee, Reece (1958). The Academic Marketplace. New York: Basic Books.

Carnegie Foundation for the Advancement of Teaching (1987). A Classification of Higher Educational Institutions. Princeton.

Chandler, Trevor L. (1988). Attracting minority graduate students and faculty in an atmosphere of increasing competition. Council of Graduate Schools (CGS) Communicator 21(June): 4-5.

Child, John (1972). Organizational structure, environment and performance: The role of strategic choice. Sociology 6(January: 1-22.

Child, John (1973). "Predicting and Understanding Organizational Structure." Administrative Science Quarterly 18 [June]: 168-185.

Conyers, James E., and Epps, Edgar G. (1974). A profile of black sociologists. In Black Sociologists: Historical and Contemporary Perspectives, J. E. Blackwell and M. Janowitz, (eds.), pp. 231-252. Chicago: University of Chicago Press.

Cyert, Richard M., and March, James G. (1963). A Behavioral Theory of the Firm. Englewood Cliffs, NJ: Prentice-Hall.

Deaux, Kay, and Ullman, Joseph C. (1983). Women of Steel. New York: Praeger.

DiNitto, Diana, Martin, Patricia Yancy, and Harrison, Dianne F. (1982). Sexual discrimination in higher education. Higher Education Review 14(Summer): 33-54.

Doeringer, Peter B., and Piore, Michael J. (1971). Internal Labor Markets and Manpower A nalysis. Lexington, MA: Heath.

Duncan, Otis D., and Duncan, Beverly (1955). A methodological analysis of segregation indexes. American Sociological Review 20(February): 210-217.

Epps, Edgar G. (1989). Academic culture and the minority professor. Academe 36: 2326.

Fernandez, John P. (1982). Racism and Sexism in Corporate Life: Changing Values in American Business. Lexington, MA: Heath.

Fleming, Jacqueline (1984). Blacks in College. San Francisco: Jossey-Bass.

Fossett, Mark, and Kiecolt, K. Jill (1989). The relative size of minority populations and white racial attitudes. Social Science Quarterly 70(December): 820-835.

Gruber, J., and Bjorn, L. (1982). Blue-collar blues: The sexual harassment of women autoworkers. Work and Occupations 9(August): 271-298.

Haggin, Joseph (1989). Program promotes educational opportunities for minority groups. Chemical and Engineering News 67(May 22): 33-34. 
Hankin, Joseph N. (1985). The status of minorities and women among the faculty and administrators of public two-year colleges, 1983-1984. Paper presented at the Annual National Convention of American Association of Community and Junior Colleges, San Diego, April 14-17.

Harris, Percy G. (1989). Almost 50 ways ... AGB Reports 31 (July-August): 32-33.

Harvey, William B. 1987. "An ebony view of the Ivory Tower: Memories of a black faculty member. Change 19(May-June): 46-49.

Harvey, William B., and Williams, Lea E. (1989). Historically black colleges: Models for increasing minority representation. Education and Urban Society 21(May): 328340.

Hill, Richard J. (1983). Minorities, women, and institutional change: Some administrative concerns. Sociological perspectives 26(January): 17-28.

Jaschik, Scott (1990). Faced with a shortage of funds, Office of Civil Rights has cut back on many of its enforcement activities. Chronicle of Higher Education 36(May 30): A17-A18.

Jensen, Eric L., and Webster, David (1981). Ranking studies of sociology departments in The American Sociologist: 1965-1980. Paper presented at the annual meeting of the American Educational Research Association, Los Angeles, April.

Jones, Lyle V., Lindzey, Gardner, and Coggeshall, Porter (eds.) (1982). An Assessment of Research-Doctorate Programs in the United States. Washington, DC: National Academy Press.

Kalleberg, Arne L., and Sorensen, Aage B. (1979). The sociology of labor markets. Annual Review of Sociology 5: 351-379.

Kanter, Rosabeth M. (1977). Men and Women of the Corporation. New York: Basic.

Kenen, Peter B., and Kenen, Regina H. (1978). Who thinks who's in charge here: Faculty perceptions of influence and power in the university. Sociology of Education 51(April): 113-123.

Kimberly, John R. (1976). Organizational size and the structuralist perspective: A review, critique and proposal. Administrative Science Quarterly 21(December): 571597.

Kulis, Stephen, Miller, Karen A., Axelrod, Morris, and Gordon, Leonard (1986a). Minorities and women in the PSA region: Five years later. Sociological Perspectives 29(April): 147-176.

Kulis, Stephen, Miller, Karen A., Axelrod, Morris, and Gordon, Leonard (1986b). Minority representation in U.S. departments. American Sociological Association Footnotes 14(5): 3, 6 .

Kulis, Stephen, Miller, Karen A., Axelrod, Morris, and Gordon, Leonard (1987). Minority representation in U.S. departments of sociology. American Sociological A ssociation Footnotes 15(1): 9, 11.

Kulis, Stephen, and Miller, Karen A. (1989). The changing sex composition of a contracting profession: Academic sociology in the early 1980s. Paper presented at American Sociological Association annual meeting, San Francisco, August 17-20.

Leashore, Bogart R. (1985). Training faculty from minority, colleges and universities for transportation research. Journal of Negro Education 54(Spring): 164-173.

Linthicum, Dorothy S. (1989). The dry pipeline: Increasing the flow of minority faculty. Paper presented at the League for Innovation in Community College Conference Leadership 2000. San Francisco, June 11-14.

Magner, Denise K. The courting of black and ethnic scholars: Bidding war or just a few new entrants in the academic star system? Chronicle of Higher Education 37(October 3): A19-A21. 
Marwell, Gerald, Rosenfeld, Rachel A., and Spilerman, Seymour (1979). Georgraphic constraints on women's careers in academia. Science 205: 1225-1231.

McGinnis, Robert, and Long, J. Scott (1988). Entry into academia: Effects of stratification, geography and ecology. In Academic Labor Markets and Careers, D. W. Breneman and T. I. K. Youn, (eds.), pp. 28-51. New York: Falmer Press.

Menges, Robert J., and Exum, William H. (1983). Barriers to the progress of women and minority faculty. Journal of Higher Education 54(March-April): 123-144.

Mooney, Carolyn J. (1989). Affirmative action goals, coupled with tiny number of minority Ph.D.'s, set off faculty recruiting frenzy. Chronicle of Higher Education 35(August 2): 10-11.

Moore, William Jr. (1988). Black faculty in white colleges: A dream deferred. Educational Record 68-69(Fall-Winter): 116-121.

Moore, William, and Wagstaff, Lonnie H. (1985). Black Educators in White Colleges: Progress and Prospects. San Francisco: Jossey-Bass.

National Research Council (1979). Survey of Earned Doctorates A warded in the United States. Washington, DC: National Research Council.

National Science Foundation (1988a). Women and Minorities in Science and Engineering. Washington, DC: National Science Foundation, Publication 88-301.

National Science Foundation (1988b). Characteristics of Doctoral Scientists and Engineers in the United States: 1987. Washington, DC: National Science Foundation, Publication 88-331.

National Science Foundation (1990). Women and Minorities in Science and Engineering. Washington, DC: National Science Foundation, Publication 90-301.

New Jersey State Department of Higher Education (1986). Affirmative Action Status Report: New Jersey Public Colleges and Universities, 1977-1985. Trenton: New Jersey State Dept. of Higher Education.

Newby, James E. (1982). Teaching Faculty in Black Colleges and Universities. Washington, DC: University Press of America.

Nickson, Sheila J. (1982). Status of minority professionals on majority campuses: Saviors, Victims, or Survivors. Paper presented at the National Association for Equal Opportunity in Higher Education, Washington, DC, March 26.

Northcraft, G. B., and Martin, J. (1982). Double jeopardy: Resistance to affirmative action from potential beneficiaries. In Sex Role Stereotyping and Affirmative Action Policy, B. A. Gutek (ed.), pp. 81-130. Los Angeles: UCLA Institute of Industrial Relations.

Pearson, Willie, Jr. (1985). Baccalaureate origins of black American scientists: A cohort analysis. Journal of Negro Education 54(1): 24-34.

Perrucci, Carolyn C. (1986). Gender equity in sociology faculty employment patterns: A cross-university comparison. Sociology and Social Research 70(April): 235-241.

Pettigrew, Thomas F., and Martin, Joanne (1987). Shaping the organizational context for black American inclusion. Journal of Social Issues 43(1): 41-78.

Pfeffer, Jeffrey (1977). Toward an examination of stratification in organizations. Administrative Science Quarterly 22(December): 553-567.

Pfeffer, Jeffrey, and Salancik, Gerald R. (1978). The External Control of Organizations. New York: Harper and Row.

Salancik, Gerald R. (1979). Interorganizational dependence and responsiveness to affirmative action: The case of women and defense contractors. Academy of Management Journal 22(September): 375-394.

Smelser, Neil, and Content, Robin (1980). The Changing A cademic Market. Berkeley: University of California Press. 
Stepina, Nancy, and Campbell, Joann (1987). Longitudinal tenure and attrition rate study in the State University System of Florida. Paper presented at the Annual Forum of the Association of Institutional Research, Kansas City, May 3-6.

Sudarkasa, Niara (1987). Affirmative action or affirmation of the status quo? Black faculty and administrators in higher education. American A ssociation of Higher Education Bulletin (February): 3-6.

Szafran, Robert F. (1982). What kinds of firms hire and promote women and blacks? A review of the literature. The Sociological Quarterly 23(Spring): 171-190.

Szafran, Robert F. (1984). Universities and Women Faculty: Why Some Organizations Discriminate More Than Others. New York: Praeger.

Theil, Henri, and Finizza, Anthony J. (1971). A note on the measurement of racial integration of schools by means of informational concepts. Journal of Mathematical Sociology 1(July): 187-194.

Williams, Lea E. (1985). The plight of junior faculty at black private colleges. Journal of the National A ssociation of Women Deans, Administrators, and Counselors 48(Winter): 12-18.

Wilson, Reginald (1987). Recruitment and retention of minority faculty and staff. American A ssociation of Higher Education (AAHE) Bulletin (February): 11-14.

Wood, John J. (1988). Barriers to Minority Access and Persistence in A rizona's Universities: Perceptions of Students, Faculty, Staff and Administrators. Phoenix: Arizona Board of Regents.

Received May 5, 1991. 